\title{
Effects of pomegranate (Punica granatum $L$.) juice as a short-term water supplement during the peak production cycle in laying hens
}

\author{
Eyüp Eren GÜLTEPE ${ }^{1, a, \bowtie}$, Aamir IQBAL ${ }^{1, b}$, İbrahim Sadi ÇETİNGÜL ${ }^{1, c}$, Cangir UYARLAR $^{1, d}$, \\ Ümit ÖZÇINAR ${ }^{1, \mathrm{e}}$, İsmail BAYRAM ${ }^{1, \mathrm{f}}$
}
${ }^{1}$ Afyon Kocatepe University, Facult of Veterinary Medicine, Department of Animal Nutrition and Nutritional Diseases, Afyonkarahisar, Turkey.
aORCID: 0000-0002-2404-1232; ' 'ORCID: 0000-0003-4473-2329; ' $\mathrm{ORCID:} \mathrm{0000-0002-7608-6176;}$ dORCID: 0000-0002-7803-2454; ' $\mathrm{ORCID:} \mathrm{0000-0002-1143-1215;} \mathrm{f} \mathrm{ORCID:} \mathrm{0000-0002-9993-7092.}$

${ }^{\square}$ Corresponding author: eegultepe@gmail.com

Received date: 20.10.2020 - Accepted date: 16.06.2021

\begin{abstract}
The objective of the study was to explore the effects of pomegranate juice (PJ) as a water supplement on performance, egg quality, and blood parameters in laying hens. For this purpose, a total of 72 Babcock laying hens, were divided into three groups, one control and two experiments $(n=24)$. Each main group consists of 4 subgroups, and each subgroup consists of 6 chickens. PJ was administered in drinking water at $0 \%, 5 \%$, and $10 \%$ to the experimental groups for 4 weeks. Feed was offered to all groups ad libitum. The addition of PJ had no significant effect on performance parameters, Haugh unit, and egg breaking strength. The yolk color of the $5 \%$ PJ group was found to be lighter than the control and other experimental groups $(\mathrm{P}<0.05)$. The PJ did not affect serum glucose levels, serum lipid profile, liver enzyme levels, serum total protein levels, most of the hematological parameters, and serum Ca:P ratio in the present study, whereas there were linear and quadratic dose responses in AST, ALT, and HDL. Serum total Ca and P levels of $5 \%$ PJ supplemented birds were lower than $10 \%$ supplemented PJ birds, whereas it was similar to the control for both $(\mathrm{P}<0.05)$. Serum $\mathrm{IgG}$ levels were lower in both treatment groups than the control group $(\mathrm{P}<0.05)$. In conclusion, using $5 \%$ of $\mathrm{PJ}$ as a short-term water supplement have some specific effects on the cholesterol metabolism of laying hens rather than performance and immunity.

Keywords: Cholesterol, phenolic content, water additive, yolk color.
\end{abstract}

\section{Kısa dönemli içme suyu katkısı olarak kullanılan nar (Punica granatum L.) suyunun pik verim dönemindeki yumurtacı tavuklara etkileri}

Özet: Çalışmanın amacı, bir içme suyu katkısı olarak nar suyunun (NS) yumurtacı tavuklarda performans, yumurta kalitesi ve kan parametreleri üzerine etkilerini incelemekti. Bu amaçla, toplamda 72 Babcock yumurtacı tavuk; biri kontrol, ikisi deneme olmak üzere 3 gruba ayrıldı $(n=24)$. Her ana grup her biri 6 tavuk içeren 4 tekerrürden oluştu. Dört hafta boyunca deneme gruplarının içme sularına $\% 0, \% 5$ ve $\% 10$ NS katıldı. Yem ad libitum sağlandı. Nar suyu ilavesinin performans parametreleri, Haugh birimi ve yumurta kabuk kırılım mukavemeti üzerine önemli bir etkisi olmadı. \%5 NS grubunda yumurta sarı rengi kontrol ve diğer deneme grubundan daha açık bulundu $(\mathrm{P}<0,05)$. Çalışmada NS, serum glikoz düzeylerini, serum lipit profilini, karaciğer enzim düzeylerini, serum total protein düzeylerini, hematolojik parametrelerin çoğunu ve serum Ca:P oranını etkilemezken; AST, ALT ve HDL'de lineer ve kuadratik doz yanıtları oluştu. \%5 NS katkılı tavuklarda serum toplam Ca ve P düzeyleri \%10 NS katkılı tavuklardan daha düşük olmuşken $(\mathrm{P}<0,05)$; kontrol her ikisine de benzer oldu. Serum IgG düzeyleri her iki uygulama grubunda da kontrol grubuna göre düşüktü $(\mathrm{P}<0 ; 05)$. Sonuç olarak; kısa dönem içme suyu katkısı olarak \%5 NS, yumurtacı tavuklarda performans ve bağışıklıktan daha ziyade kolesterol metabolizması üzerine bazı spesifik etkilere sahiptir.

Anahtar sözcükler: Fenolik içerik, kolesterol, su katkısı, yumurta sarı rengi.

\section{Introduction}

The poultry sector plays an important role in every country's economy and poultry is also one of the most economical and easily accessible protein sources. Many experiments are currently underway to make poultry products better for human health, while humans of all ages consume poultry products such as eggs and meat. In the past, many synthetic antibiotics have been used to protect the health and development of poultry. Currently, herbal extracts are also being explored for their potential as a substitute for synthetic antibiotics without affecting the profitability of poultry businesses in last two decades (5). 
Pomegranate (Punica granatum L.) is one of the ancient fruit and belongs to the Punicacea family. It is mostly cultivated in subtropical regions. Turkey is known as one of the motherland of pomegranate and is among the top four in world production (22). Aril is the edible part of pomegranate and it consists of $52 \%(\mathrm{w} / \mathrm{w})$ of the total fruit and comprises $78 \%$ juice and $22 \%$ seeds. The seed of pomegranate is rich in polyunsaturated fatty acids (PUFA), polyphenols, minerals, sugars, vitamins, and polysaccharides (19). Therefore, fruit and byproducts (pulp, juice, oil, and extract) of pomegranate are investigated as a phytochemical source in poultry nutrition (3) as well as human nutrition (30). Similarly, pomegranate juice (PJ) has some anti-inflammatory, antioxidant, anti-atherogenic, and antimicrobial effects due to abundant presence of anthocyanin, ellagic acid derivatives, and hydrolyzable tannins (9). Recently, the molecular effects of pomegranate on lipid metabolism have been reviewed in detail by Hou et al. (14). The authors stated that the active ingredients of pomegranate have widespread effects on a lot of key proteins and genes in the lipid metabolism. Although much research has been done on dietary pomegranate supplementation and its components, there are limited data available on the effects of the PJ supplement in laying hens.

Previous evidence suggests that the supplementation route of additives may lead to a different response in the poultry. Noy and Sklan (21) concluded that in the early stages of the life of the chicks, carbohydrates supplied with drinking water were more effective than dietary carbohydrates. Similarly, Ritzi et al. (23) noted that probiotics as a water supplement had a better impact on broiler feed efficiency compared with the same dietary probiotics. Recently, we observed some different effects of lemon juice, plant extracts, and pomegranate molasses as water additives for laying hens at different production cycles in our research lab, as compared to dietary counterparts of mentioned supplements $(11,12,15)$.

Keeping in view the above points, the present study was conducted to investigate the effects of different levels of pomegranate juice on performance, egg quality trait, and blood parameters in laying hens. It was hypothesized that the PJ could sustain and improve the peak production phase of laying hens due to its high antioxidant potential. Also, it was hypothesized that water supplementation route could lead to an improvement on performance parameters on a short-term basis rather than extracts or byproducts in a long-term basis.

\section{Materials and Methods}

The current study was conducted at Afyon Kocatepe University Animal Research Center, Afyonkarahisar, following approval by the Local Ethics Committee on Animal Ethical Use under approval No:49533702/119, dated: 07/09/2016.
Birds, experimental design and management: A total of 72 white laying hens (Babcock) aged 30 weeks were divided into three groups with one control group and two treatment groups $(n=24)$ and divided into four subgroups of 6 hens each. The conditions in cage were similar to the previous experiment of our research group (12). In summary, birds were housed in battery cages (width $=48 \mathrm{~cm} \times$ depth $=45 \mathrm{~cm} \times$ height $=45 \mathrm{~cm})(2$ birds/cage, $1080 \mathrm{~cm} / \mathrm{hen}$ density). Throughout the experiment, the room temperature was recorded for 24 hours a day. The laying hens were provided with sixteen hours of light and eight hours of dark, along with ad libitum feed and free access water. Pomegranate juice was added to all treatment groups with different concentrations i.e. $0 \%, 5 \%$, and $10 \%$ respectively for 4 weeks. In this study, a basal diet was fed to all treatment groups, which was formulated according to the bird's requirement (Table 1) (20).

Table 1. Composition of the basal diet.

\begin{tabular}{|c|c|}
\hline Ingredients & $\%$ \\
\hline Corn & 54.90 \\
\hline Vegetable oil & 0.34 \\
\hline Sunflower meal (\%32 CP) & 16.93 \\
\hline Full fat soya & 10.00 \\
\hline Soyabean meal (\%44 CP) & 7.39 \\
\hline Limestone & 7.87 \\
\hline Dicalcium phosphate & 1.73 \\
\hline Salt & 0.40 \\
\hline Vitamin-mineral mixture* & 0.25 \\
\hline L-lysine $\mathrm{HCl}$ & 0.10 \\
\hline DL-methionine & 0.10 \\
\hline \multicolumn{2}{|l|}{ Calculated analyses (\%) } \\
\hline DM.\% & 87.5 \\
\hline СР.\% & 16.8 \\
\hline Ether ext.\% & 4.1 \\
\hline CF.\% & 5.6 \\
\hline Ash \% & 11.5 \\
\hline ME.kcal/kg** & 2750 \\
\hline Сa. $\% * *$ & 3.71 \\
\hline Av.P.\%** & 0.38 \\
\hline Na. $\% * *$ & 0.20 \\
\hline Met + Cys $\% * *$ & 0.71 \\
\hline Lysine.\%** & 0.83 \\
\hline Threonine $(\%)^{* *}$ & 0.61 \\
\hline Tryptophan $(\%)^{* *}$ & 0.20 \\
\hline Linoleic acid $(\%)^{* *}$ & 2.36 \\
\hline
\end{tabular}

*Provided per kg of diet: Vitamin A: 12.000.000 IU, Vitamin D3: 3.000.000IU, Vitamin E: 35.000, Vitamin K3: 3.500 , Vitamin B1: 2.750IU, Vitamin B2: 5.500IU, Nicotinamid: 30.000IU, Ca-D-Panthotenate: 10.000IU, Vitamin B6: 4.000IU, Vitamin B12-15IU, Folic acid: 1.000IU, D-Biotin: 50IU,Cholin clorid: $150.000 \mathrm{IU}$, Manganese: $80.000 \mathrm{mg}$, Iron: $60.000 \mathrm{mg}$, Zinc: $60.000 \mathrm{mg}$, Copper: $5.000 \mathrm{mg}$, Iodine: $2.000 \mathrm{mg}$, Cobalt: $500 \mathrm{mg}$, Selenium: $150 \mathrm{mg}$, Antioxidant: $15.000 \mathrm{mg}$ **Calculated 
The experimental diet was prepared, mixed, and packaged at the Animal Research Center. The diet was offered as a mash form. Pomegranate juice (PJ) was prepared and poured in fresh drinking water regularly. The pomegranate fruit was purchased from a local fruit trader weekly and was stored at room temperature until obtaining the juice at the Animal Research Center. A manual hand press was used to obtain the PJ from arils, seeds, and pulp membranes together after removing the outer peels with a knife. After pressing, a metal strainer was used to remove any potential particle from rind, peel, seed or pulp of the fruit. Automatic nipple drinking system was used and each group has a separate water tank. Graduated cylinder glass was used for the scaling of the PJ. Then, PJ was mixed with tap water in a 20-liter water box between 1 p.m. to 2 p.m. every day. The product was easily soluble in the water and homogeneity was confirmed visually. During the study, the water in each tank (control $0 \%, 5 \%$, and $10 \%$ ) was refreshed after every 24 hours.

Data collection, calculations, and analyses: Hens were weighted at the beginning and at the end of the study to determine their body weights. No mortality was recorded during the study. Hen-day egg production (HDEP) was recorded daily and feed intake and egg weight of hens were recorded weekly. Egg mass (EM) was calculated as follows:

EM $(\mathrm{g})=\operatorname{HDEP}(\%) \times$ Egg weight $(\mathrm{g})$.

Feed conversion ratio (FCR) values were calculated as follows:

$\mathrm{FCR}=$ feed intake $(\mathrm{g}) /$ egg mass $(\mathrm{g})$.

At the end of the 4th week, three eggs from each subgroup were collected to determine the parameters of the egg quality. The eggs were kept for 24 hours at room temperature before the egg trait analyses. In these eggs, the eggshell breaking strengths were measured with a semi-automated egg force reader (Model EF 0468-2011, ORKA Food Technology Ltd., Israel) after weighting with a digital scale (two decimal place). The eggs were then poured individually onto a flat glass plate. The heights of the albumen were measured using a digital micrometer. Haugh Unit has been estimated according to: Haugh Unit $=100 \times \log \left(\mathrm{h}-1.7 \mathrm{w}^{0.37}+7.6\right)$; where $\mathrm{h}$ is albumen height $(\mathrm{mm})$ and $\mathrm{w}$ is egg weight $(\mathrm{g})$. Three independent laboratory inspectors measured egg yolk color at the same time using Roch Improved Yolk Color Fan (15 bands) on the flat glass under daylight. At the end of the trial, 3 hens from each replicate were randomly selected, and blood was drawn from the heart into two separate vacutainers with and without the heparin as an anticoagulant. Blood samples arrived in the laboratory within 2 hours under a cold chain. Total blood analyser (BC 2800 Vet, Mindray Medical International Ltd., Shenzhen, China) analyzed the samples in heparinized tubes for hematological parameters (Total leukocyte count, WBC; Heterophil count, HC; Neutrophil count, NC; Monocyte count, MC;
Red blood cell count, RBC; Hemoglobin, He; Mean corpuscular volume, MCV; Mean corpuscular hemoglobin, MCH; Mean corpuscular hemoglobin concentration, MCHC; Platelet, PLT; Mean platelet volume, MPV). The analyser determined hematocrit levels as follows: $\mathrm{Ht}=(\mathrm{MCV} \times \mathrm{RBC}) \times 0.1$. For serum biochemical analyses, the samples in vacutainer tubes were centrifuged at $5000 \mathrm{rpm}$ for 10 minutes. Supernatants were transferred to Eppendorf tubes and stored at $-20{ }^{\circ} \mathrm{C}$ till biochemical analyses. Serum glucose, total cholesterol (CHO), high density lipoprotein (HDL), low density lipoprotein (LDL), aspartate aminotransferase (AST), alanine aminotransferase (ALT), GammaGlutamyl Transpeptidase (GGT), total protein (TPRO), phosphorus, calcium and Immunoglobulin G (IgG) concentrations were determined by automated ELISA analyser (Elisys Uno, Human mbH, Wiesbaden, Germany) in a commercial diagnostic laboratory.

Phenolic content of the samples was determined using the Folin-Ciocalteu method (13) with slight modifications. Absorbance was read at $765 \mathrm{~nm}$. The results were expressed as gallic acid equivalents (GAE) in $\mathrm{mg}$ GAE/L \pm standard deviation. The data were obtained from the average of three determinations. Also, the effect of $\mathrm{PJ}$ on $\mathrm{pH}$ levels of drinking water was simulated in vitro with a portable digital $\mathrm{pH}$ meter at $0 \mathrm{~h}$ and $23^{\text {rd }} \mathrm{h}$.

Statistical analysis: The data were analyzed in a randomized block design with cage as the experimental unit. The data was evaluated using the MIXED procedure of SAS (version 9.4, SAS Institute, Carry, NC) with the fixed effects of treatment. Cage and replicate (subgroup) were included as random effects. Degrees of freedom were calculated by using Kenward-Roger approach in the MODEL statement of SAS. The PDIFF statement was used for multiple comparisons as a post-hoc test. Outliers were deleted if studentized residuals $>4$ or $<-4$ before the analysis. Then, normality tests (Shapiro-Wilk test, Kolmogorov-Smirnov test, Anderson-Darling test, and Cramer-von Mises test) were performed with UNIVARIATE statement of SAS and all data had a normal distribution. The polynomial contrasts (control vs. treatment diets, linear and quadratic trends) were used to evaluate responses to the PJ supplementation with different doses. Coefficients of contrasts were validated with IML procedure of SAS (17). All data are reported as LSMEANS with SEM in tables. The significance level was set at $\mathrm{P} \leq 0.05$ for main effect and control vs. treatment contrast and it was assumed at $0.05<\mathrm{P} \leq 0.15$ for tendency (linear and quadratic).

\section{Results}

The total phenolic content of the PJ was $3661.9 \pm$ $209.9 \mathrm{mg}$ gallic acid equivalent $(\mathrm{GAE}) / \mathrm{L}$. Also, the average $\mathrm{pH}$ of tap water with $0 \%, 5 \%, 10 \%$ supplemental PJ were 6.92, 4.53, and 4.01, respectively. 
Initial body weight $(\mathrm{BW})$ was similar among the group before the study $(\mathrm{P}=0.64)$. Similarly, PJ supplementation to drinking water did not affect the final BW of the birds after 4 weeks. Also, feed intake, egg production, FCR, egg mass, and egg weights were not affected by PJ supplementation during the study. There was no difference in control vs treatments $(5 \%$ and $10 \%$ supplemented PJ) contrasts or trend analysis for increased PJ levels in the drinking water (Table 2).

The PJ supplementation did not affect the breaking strength and Haugh Unit of the eggs $(\mathrm{P}=0.60$ and $\mathrm{P}=0.42$, respectively). Also, there was no linear or quadratic trend of the aforementioned parameters as a response to increased PJ drinking water supplementation. However, yolk colors of eggs were significantly lighter in $5 \%$ supplemented PJ group than the eggs from other groups $(\mathrm{P}=0.047)$. Although there was no significant difference for control $v s$ treatments ( $5 \%$ and 10\% supplemented PJ), there was a quadratic trend to respond to increased PJ supplementation $(\mathrm{P}=0.08)$ in yolk color (Table 3$)$.

Supplementation of PJ to drinking water did not affect serum glucose levels, serum lipid profile, liver enzyme levels, and serum total protein levels in the present study. Also, there were no control vs treatments differences (5\% and 10\% supplemented $\mathrm{PJ})(\mathrm{P}>0.15)$ for the mentioned parameters. However, there was a linear trend for increased levels of PJ supplementation for both serum levels of AST and $\operatorname{ALT}(\mathrm{P}=0.12$ and $\mathrm{P}=0.10$, respectively). Also, serum HDL levels had a quadratic trend for increased levels of PJ supplementation in the study $(\mathrm{P}=0.07)$. Serum total phosphorus and serum total calcium levels of 5\% PJ supplemented laying hens were significantly lower than the $10 \%$ PJ supplemented birds $(\mathrm{P}=0.049$ and $\mathrm{P}=0.04$, respectively), while the control birds had no significant difference compared with both treatment groups for mentioned parameters. Also, both parameters had a quadratic response to increased PJ supplementation ( $\mathrm{P}=0.06$ for phosphorus and $\mathrm{P}=0.08$ for calcium). Although PJ drinking water supplementation had no main effect on serum $\mathrm{Ca}: \mathrm{P}(\mathrm{P}=0.35)$, the ratio had a quadratic response to increased $\mathrm{PJ}$ supplementation $(\mathrm{P}=0.15)$. Serum IgG levels of both 5\% PJ supplemented and $10 \%$ PJ supplemented birds were significantly lower than the control birds $(\mathrm{P}=0.03)$. Also, there was a significant difference for the control vs treatments $(5 \%$ and $10 \%$ PJ supplementation) contrast. $(\mathrm{P}=0.02)$. Both a linear and a quadratic response were observed on serum IgG levels of birds during PJ supplementation to drinking water from $0 \%$ to $10 \%(\mathrm{P}=0.06$ and $\mathrm{P}=0.15$, respectively $)$ (Table 4).

Table 2. Effects of short-term water supplement of pomegranate juice on performance of laying hens during peak period ${ }^{1}$.

\begin{tabular}{|c|c|c|c|c|c|c|c|c|}
\hline \multirow[b]{3}{*}{ Item } & \multicolumn{4}{|c|}{ Treatments } & \multicolumn{4}{|c|}{ P-values } \\
\hline & & & & & \multirow{2}{*}{ Treatment } & \multicolumn{3}{|c|}{ Contrast $^{6}$} \\
\hline & $0 \%$ & $5 \%$ & $10 \%$ & SEM $^{5}$ & & $\mathrm{C} v s \mathrm{~T}$ & Linear & Quadratic \\
\hline Feed intake, g/day & 104.38 & 98.00 & 103.13 & 5.31 & 0.68 & 0.57 & 0.87 & 0.40 \\
\hline Egg weight, g & 59.68 & 59.88 & 59.39 & 0.78 & 0.91 & 0.96 & 0.80 & 0.73 \\
\hline HDEP, $\%^{2}$ & 80.66 & 77.88 & 78.89 & 4.00 & 0.89 & 0.65 & 0.76 & 0.71 \\
\hline Egg mass, g & 48.10 & 46.56 & 46.83 & 2.17 & 0.87 & 0.61 & 0.69 & 0.74 \\
\hline $\mathrm{FCR}^{3}$ & 2.18 & 2.11 & 2.23 & 0.14 & 0.86 & 0.97 & 0.81 & 0.63 \\
\hline Initial $\mathrm{BW}^{4}, \mathrm{~g}$ & 1591.43 & 1625.82 & 1630.28 & 31.72 & 0.64 & 0.35 & 0.39 & 0.70 \\
\hline Final $\mathrm{BW}^{4}, \mathrm{~g}$ & 1480.38 & 1542.30 & 1536.24 & 37.62 & 0.44 & 0.21 & 0.30 & 0.46 \\
\hline
\end{tabular}

${ }^{1}$ Data are represented as least square means. The values are means of 4 replicate cages per diet with 6 hens $(n=24)$.

${ }^{2}$ Hen day egg production.

${ }^{3} \mathrm{Feed}$ conversion ration

${ }^{4}$ Body weight

${ }^{5}$ Standard error of the mean

${ }^{6}$ Coefficients of contrast for unequally spaced particle size levels were calculated using PROC IML of SAS

$a, b, c$ Values with different superscripts in the same column are significantly different $(\mathrm{P} \leq 0.05)$ and for tendency declared at $0.05<\mathrm{P}<0.15$.

Table 3. Effects of short-term water supplement of pomegranate juice on egg traits of laying hens during peak period ${ }^{1}$.

\begin{tabular}{|c|c|c|c|c|c|c|c|c|}
\hline \multirow[b]{3}{*}{ Item } & \multicolumn{4}{|c|}{ Treatments } & \multicolumn{4}{|c|}{ P-values } \\
\hline & \multirow[b]{2}{*}{$0 \%$} & \multirow[b]{2}{*}{$5 \%$} & \multirow[b]{2}{*}{$10 \%$} & \multirow[b]{2}{*}{ SEM $^{2}$} & \multirow{2}{*}{ Treatment } & \multicolumn{3}{|c|}{ Contrast $^{3}$} \\
\hline & & & & & & $\mathrm{C} v s \mathrm{~T}$ & Linear & Quadratic \\
\hline Breaking Strenght, $\mathrm{kg} / \mathrm{cm}^{2}$ & 40.63 & 36.79 & 37.67 & 2.78 & 0.60 & 0.33 & 0.46 & 0.49 \\
\hline Haugh Unit & 71.70 & 66.50 & 65.12 & 3.64 & 0.42 & 0.20 & 0.21 & 0.67 \\
\hline Yolk Color & $6.41^{\mathrm{a}}$ & $5.29^{\mathrm{b}}$ & $5.88^{\mathrm{ab}}$ & 0.39 & 0.05 & 0.09 & 0.34 & 0.08 \\
\hline
\end{tabular}

${ }^{1}$ Data are represented as least square means. The values are means of 4 replicate cages per diet with 6 hens $(n=24)$.

${ }^{2}$ Standard error of the mean

${ }^{3}$ Coefficients of contrast for unequally spaced particle size levels were calculated using PROC IML of SAS

a,b,c Values with different superscripts in the same column are significantly different $(\mathrm{P} \leq 0.05)$ and for tendency declared at $0.05<\mathrm{P}<0.15$. 
Table 4. Effects of short-term water supplement of pomegranate juice on serum biochemical parameters of laying hens during peak period $^{1}$.

\begin{tabular}{|c|c|c|c|c|c|c|c|c|}
\hline \multirow[b]{3}{*}{ Item } & \multicolumn{4}{|c|}{ Treatments } & \multicolumn{4}{|c|}{ P-values } \\
\hline & & & & & \multirow{2}{*}{ Treatment } & \multicolumn{3}{|c|}{ Contrast $^{9}$} \\
\hline & $0 \%$ & $5 \%$ & $10 \%$ & SEM $^{8}$ & & $\mathrm{C} v s \mathrm{~T}$ & Linear & Quadratic \\
\hline Glucose, $\mathrm{mg} / \mathrm{dL}$ & 220.10 & 224.60 & 206.60 & 10.13 & 0.44 & 0.72 & 0.35 & 0.37 \\
\hline Cholesterol, mg/dL & 84.50 & 82.60 & 93.00 & 12.23 & 0.82 & 0.83 & 0.63 & 0.68 \\
\hline $\mathrm{HDL}^{2}, \mathrm{mg} / \mathrm{dL}$ & 21.10 & 27.70 & 21.90 & 2.70 & 0.19 & 0.27 & 0.84 & 0.07 \\
\hline $\mathrm{LDL}^{3}, \mathrm{mg} / \mathrm{dL}$ & 35.70 & 29.90 & 36.50 & 7.55 & 0.80 & 0.79 & 0.94 & 0.51 \\
\hline $\mathrm{AST}^{4}, \mathrm{U} / \mathrm{L}$ & 188.20 & 227.56 & 226.90 & 17.46 & 0.20 & 0.08 & 0.12 & 0.37 \\
\hline $\mathrm{ALT}^{5}, \mathrm{U} / \mathrm{L}$ & 2.10 & 2.50 & 3.60 & 0.62 & 0.23 & 0.22 & 0.10 & 0.65 \\
\hline $\mathrm{GGT}^{6}, \mathrm{U} / \mathrm{L}$ & 28.10 & 29.10 & 30.00 & 1.86 & 0.77 & 0.53 & 0.48 & 0.98 \\
\hline Total Protein, g/dL & 4.81 & 4.99 & 4.92 & 0.32 & 0.92 & 0.72 & 0.81 & 0.75 \\
\hline Phosphorus, mg/dL & $4.78^{\mathrm{ab}}$ & $4.01^{\mathrm{b}}$ & $5.18^{\mathrm{a}}$ & 0.40 & 0.05 & 0.71 & 0.49 & 0.06 \\
\hline Calcium, mg/dL & $18.69^{\mathrm{ab}}$ & $17.18^{\mathrm{b}}$ & $20.64^{\mathrm{a}}$ & 1.11 & 0.04 & 0.87 & 0.22 & 0.08 \\
\hline $\mathrm{Ca} / \mathrm{P}$ & 4.03 & 4.66 & 4.07 & 0.33 & 0.35 & 0.42 & 0.93 & 0.15 \\
\hline $\mathrm{IgG}^{7}, \mathrm{mg} / \mathrm{dL}$ & $48.26^{\mathrm{a}}$ & $17.19^{\mathrm{b}}$ & $21.42^{\mathrm{b}}$ & 9.64 & 0.03 & 0.02 & 0.06 & 0.15 \\
\hline
\end{tabular}

${ }^{1}$ Data are represented as least square means. The values are means of 4 replicate cages per diet with 6 hens $(\mathrm{n}=24)$.

${ }^{2}$ High density lipoprotein

${ }^{3}$ Low density lipoprotein

${ }^{4}$ Aspartate transaminase

${ }^{5}$ Alanine transaminase

${ }^{6}$ Gamma-glutamyl transferase

${ }^{7}$ Immunoglobulin G

${ }^{8}$ Standard error of the mean

${ }^{9}$ Coefficients of contrast for unequally spaced particle size levels were calculated using PROC IML of SAS

a,b,c Values with different superscripts in the same column are significantly different $(\mathrm{P} \leq 0.05)$ and for tendency declared at $0.05<\mathrm{P}<0.15$.

Table 5. Effects of short-term water supplement of pomegranate juice on hematology parameters of laying hens during peak period ${ }^{1}$.

\begin{tabular}{|c|c|c|c|c|c|c|c|c|c|}
\hline \multirow[b]{3}{*}{ Item } & \multicolumn{4}{|c|}{ Treatments } & \multirow{3}{*}{ Reference } & \multicolumn{4}{|c|}{ P-values } \\
\hline & \multirow[b]{2}{*}{$0 \%$} & \multirow[b]{2}{*}{$5 \%$} & \multirow[b]{2}{*}{$10 \%$} & \multirow[b]{2}{*}{ SEM $^{14}$} & & \multirow{2}{*}{ Treatment } & \multicolumn{3}{|c|}{ Contrast $^{15}$} \\
\hline & & & & & & & $\mathrm{C} v s \mathrm{~T}$ & Linear & Quadratic \\
\hline $\mathrm{WBC}^{2}, \times 10^{10} / \mathrm{L}$ & 220.10 & 224.60 & 206.60 & 10.13 & $1.2-3.0$ & 0.44 & 0.72 & 0.35 & 0.37 \\
\hline $\mathrm{HC}^{3}, \times 10^{10} / \mathrm{L}$ & 84.50 & 82.60 & 93.00 & 12.23 & $0.7-1.76$ & 0.82 & 0.83 & 0.63 & 0.68 \\
\hline $\mathrm{NC}^{4}, \times 10^{10} / \mathrm{L}$ & 21.10 & 27.70 & 21.90 & 2.70 & $0.3-0.6$ & 0.19 & 0.27 & 0.84 & 0.07 \\
\hline $\mathrm{MC}^{5}, \mathrm{x} 10^{10} / \mathrm{L}$ & 35.70 & 29.90 & 36.50 & 7.55 & $0.01-0.20$ & 0.80 & 0.79 & 0.94 & 0.51 \\
\hline $\mathrm{RBC}^{6}, \mathrm{x} 10^{12} / \mathrm{L}$ & 188.20 & 227.56 & 226.90 & 17.46 & $2.5-3.5$ & 0.20 & 0.08 & 0.12 & 0.37 \\
\hline $\mathrm{He}^{7}, \mathrm{~g} / \mathrm{dL}$ & 2.10 & 2.50 & 3.60 & 0.62 & $7-13$ & 0.23 & 0.22 & 0.10 & 0.65 \\
\hline $\mathrm{Ht}^{8}, \%$ & 28.10 & 29.10 & 30.00 & 1.86 & $32-36$ & 0.77 & 0.53 & 0.48 & 0.98 \\
\hline $\mathrm{MCV}^{9}, \mathrm{fL}$ & 4.81 & 4.99 & 4.92 & 0.32 & $90-140$ & 0.92 & 0.72 & 0.81 & 0.75 \\
\hline $\mathrm{MCH}^{10}, \mathrm{pg}$ & $4.78^{\mathrm{ab}}$ & $4.01^{\mathrm{b}}$ & $5.18^{\mathrm{a}}$ & 0.40 & $33-47$ & 0.05 & 0.71 & 0.49 & 0.06 \\
\hline $\mathrm{MCHC}^{11}, \%$ & $18.69^{\mathrm{ab}}$ & $17.18^{\mathrm{b}}$ & $20.64^{\mathrm{a}}$ & 1.11 & $26-35$ & 0.04 & 0.87 & 0.22 & 0.08 \\
\hline $\mathrm{PLT}^{12}, \times 10^{10} / \mathrm{L}$ & 4.03 & 4.66 & 4.07 & 0.33 & n.a. & 0.35 & 0.42 & 0.93 & 0.15 \\
\hline $\mathrm{MPV}^{13}, \mathrm{fL}$ & $48.26^{\mathrm{a}}$ & $17.19^{b}$ & $21.42^{\mathrm{b}}$ & 9.64 & n.a. & 0.03 & 0.02 & 0.06 & 0.15 \\
\hline
\end{tabular}

${ }^{1}$ Data are presented as least square means. The values are means of 4 replicate cages per diet with 6 hens $(n=24)$.

${ }^{2}$ White blood cell, total leukocyte count

${ }^{3}$ Heterophil count

${ }^{4}$ Neutrophil count

${ }^{5}$ Monocyte count

${ }^{6}$ Red blood count

${ }^{7}$ Hemoglobin

${ }^{8}$ Hematocrit

${ }^{9}$ Mean corpuscular volume

${ }^{10}$ Mean corpuscular hemoglobin

${ }^{11}$ Mean corpuscular hemoglobin concentration

${ }^{12}$ Platelet

${ }^{13}$ Mean platelet volume

${ }^{14}$ Standard error of the mean

${ }^{15}$ Coefficients of contrast for unequally spaced particle size levels were calculated using PROC IML of SAS

a,b,c Values with different superscripts in the same column are significantly different $(\mathrm{P} \leq 0.05)$ and for tendency declared at $0.05<\mathrm{P}<0.15$. 
Drinking water supplementation of PJ did not affect hematological parameters in the study, except mean corpuscular hemoglobin concentration $(\mathrm{MCH})$ which was significantly higher in 5\% PJ supplemented groups than the other groups $(\mathrm{P}=0.02)$. Also, there was a control vs treatments contrast in MHC levels $(\mathrm{P}=0.05)$. Quadratic trends for white blood cell count (WBC), MC, hemoglobin level, and MPV were observed as a response to increased $\mathrm{PJ}$ supplementation from $0 \%$ to $10 \%(\mathrm{P}=0.11, \mathrm{P}=0.06$, $\mathrm{P}=0.15$, and $\mathrm{P}=0.08$, respectively) (Table 5).

\section{Discussion and Conclusion}

Researchers have been interested in pomegranate fruit for many years because of the abundance of polyphenolic flavonoid content and a broad range of health effects (30). Gozlekci et al (10) reported that the total phenolic content in PJ was lower than the PJ used in the current study (1218.2 vs $3661.9 \mathrm{mg} \mathrm{GAE} / \mathrm{L})$. The same researchers observed that pomegranate peels had the highest total phenolic content among the other parts of the fruit (10). In this study, pulp membranes were not removed during the hand pressing, although outer membranes (peels) were removed. The pulp membranes may have increase the total phenolic content of PJ used in the present study.

While much research has been done on the supplementation of pomegranate and its components, there is limited data on the effects of the PJ supplementation on laying hens. In the present study, the PJ supplementation did not affect feed intake, egg production, FCR, egg mass, and egg weight. The effects of dietary pomegranate by-products on the performance of laying hens were variable in previous reports. Kostogrys et al. (16) reported increased feed intake, egg production, and egg mass as a dose-dependent form of supplementation of pomegranate seed oil to laying hens' diet. Similarly, Abbas et al. (2) observed an improvement in egg production and feed intake of Japanese quails supplemented with pomegranate peel powder. However, Ghahtan et al. (8) recorded no effect of dietary supplementation of $1 \%$ pomegranate peel powder on egg production in laying quails until 10 weeks of the study, whereas $2 \%$ supplemented birds were lower in egg production than the control birds in the same research. Sharma et al. (27) also determined the effects of a commercial blend which includes active ingredients from thyme and garlic as well as pomegranate as a water supplement similar to the present study in laying hens. The authors stated that water supplementation of the blend included ellagic acid from pomegranate affected egg production and feed intake for two weeks, whereas there was no effect of the blend for other time points between $65^{\text {th }}-73^{\text {rd }}$ weeks of age. While Saki et al. (24) observed significantly higher egg production in laying hens supplemented with $5 \%$ dietary pomegranate seed pulp compared to control birds, the authors noted no difference between the groups supplemented with $10 \%$ and $15 \%$ dietary pomegranate seed pulp and the control birds. Similar to our findings, the authors stated that dietary pomegranate seed pulp had no effect on feed intake, egg weight, egg mass, and FCR. In an earlier study of our research lab, we observed that both $1 \%$ and $2.5 \%$ of drinking water supplementations of lemon juice were increased egg production of aged laying hens, whereas it did not affect the lowest or highest doses of supplementation $(0.5 \%$ or $5 \%)$ inconsistent with our findings (11). However, water supplementation of lemon juice did not affect feed intake, egg weight, and FCR in the aforementioned study similar to our findings. Gil et al. (9) reported that pomegranate products' antioxidant capacity and active ingredients depend not only on the type of by-product (e.g. seed pulp, extract, juice) but also on the processing of the same type of products. The evidence suggests that variation of the effects of pomegranate by products in previous and current research on laying hens models may be explained in the aforementioned studies by different sources of pomegranate by products. Moreover, antioxidant activities of the different pomegranate by-products are variable because of different amounts of total phenolics which acts as hydrogen donors and reducing agents (10). However, the evidence from previous studies indicated that dietary supplementation of pomegranate by-products, similar to our findings, did not affect the body weight of laying hens or quails $(2,11,24)$. Although there were no significant differences between the groups related to performance parameters, it is expected that BW should be from 1651 to 1683 grams at 30-34 weeks of age according to Production Guideline (4). However, the initial weights of our experimental birds were lower than expected weights in all groups. Also, the product guide is expected 60.5-61.7 grams egg weight at the same period. It is also higher than our experiment results. It may be explained by the effect of different lines/breeders. Although there was no water intake data in the current study as a weak point, we assumed that the PJ supplementation had no negative effect on the acceptability of the drinking water. Because the strong correlation between feed and water intake is a well-known phenomena.

In the present study, the addition of PJ drinking water did not affect the breaking strength of the eggshell. In agreement with our findings, Saki et al. (24) reported no effect of dietary pomegranate seed pulp on eggshell breaking strength from laying hens. Similarly, Sharma et al. (27) did not observe any effect of a commercial blend which includes active ingredients from thyme and garlic 
as well as pomegranate as a water supplement on the eggshell breaking strength of supplemented laying hens. In an earlier study of our research lab, we stated that the addition of myrtle plant extract to drinking water did not affect the eggshell breaking strength of supplemented laying hens (12).

It is well known that eggshell thickness and specific gravity are important markers for eggshell breaking strength during the storage and processing of table eggs (29). The numerous evidence suggests that dietary supplementation of pomegranate byproducts does not affect specific gravity and eggshell thickness as an indirect marker of eggshell breaking strength in laying hens and quails $(8,27)$. Also, Saki et al. $(25)$ reported that dietary supplementation of pomegranate by products did not affect the specific gravity of eggs in the study. Although the authors observed an increase for eggshell thickness in high dose groups ( $8 \%$ and $12 \%$ supplementation), there was no observed effect in the lower dose group (4\% supplementation) in the aforementioned study. Furthermore, the previous evidence stated that water supplementation of lemon juice (11) and myrtle plant extract (12) did not affect eggshell thickness of the supplemented laying hens. In the present study, Haugh Unit was shown no improvement by supplementation of $\mathrm{PJ}$ in the drinking water of laying hens in agreement with the previous reports about dietary supplementation of pomegranate by products in laying hens and quails $(8,16$, 24, 25). However, Sharma et al. (27) reported that a commercial blend as a water supplement containing the active ingredients of thyme, garlic, and pomegranate resulted in Haugh Unit improvement in laying hens. In an earlier study of our research lab, we observed that drinking water supplementation of myrtle plant extract did not affect Haugh Units of eggs (12). However, in a consecutive study, we observed that drinking water supplementation of lemon juice led to an improvement in Haugh Unit for 1\% lemon juice, whereas there was no improvement for $0.5 \%, 2.5 \%$, and $5 \%$ lemon juice (11). The evidence suggests that supplementation route (dietary or water supplement) of the same nutrients or additives may lead to a different response in poultry $(21,23,28)$. For Haugh Unit, the conflicting results of pomegranate water supplements which were reported by Sharma et al. (27) with the others may be explained by having a different supplementation route.

In the present study, $5 \%$ of PJ water supplement resulted in lighter egg yolk. But the higher dose of PJ (10\%) did not change the egg yolk color in the study. The effects of dietary pomegranate by products have been variable. Kostogrys et al. (16) found that dietary pomegranate seed oil improved yolk color scores at the study's highest dose (1.5\%), while dietary supplementation did not alter color scores at lower doses $(0.5 \%$ and $1 \%)$. Sharma et al. (27) also confirmed that a commercial dietary supplement that is a mixture of active ingredients of thyme, garlic, and pomegranate peel has resulted in darker yolk color in treatment groups than the control birds. Different routes of supplementations (dietary supplement vs. water supplement) may explain the conflicting results from the reported studies and our findings. In an earlier study of our research lab, we stated that the myrtle plant extract that is a weak acid/neutral characteristic (pH: 5-7) (26) did not change the laying hens' yolk color (12). In agreement with our findings in birds supplemented by 5 percent PJ, we also observed that supplementation of 5 percent lemon juice which has a strong acidic characteristic led to lighter yolk color in laying hens (11). Although PJ itself has a strongly acidic (pH: 2.9-3.10) property (7), PJ-supplemented drinking water samples did not show a strong acidic characteristic compared to plain water in the present study. The lighter egg yolk color scores of 5 percent PJ supplemented birds can be explained by the high phenolic content of PJ resulting in high antioxidant activity rather than the acidic characteristic of PJ. Furthermore, we observed that water supplementation of pomegranate molasses affected yolk color and yolk index (15).

The pomegranate has beneficial effects on lipid metabolism (14). Lv et al. (18) stated that pomegranate peel polyphenols, punicalagin, and pomegranate ellagic improved cholesterol catabolism via increasing total bile acid production in the liver cells. In the present study, we observed linear response of serum ALT and serum AST levels to PJ supplementation which may be explained as an indirect result of promoting total bile acid production in the liver. Liver $X$ receptors and target gene of the mentioned receptors (ATP-binding cassette transporter A1 - ABCA1) have a key role in cholesterol metabolism of the body. Liver X receptors stimulate HDL production and the HDL contributes to cholesterol balancing by transporting peripheral tissue cholesterol to liver (14). Zhao et al. (31) observed that pomegranate polyphenol significantly increased mRNA expression of the Liver X receptor and ABCA1 in the hepatic cells. In our study, the PJ had higher total phenolic content than the previous reports (10). It may explain the observed quadratic response of HDL to PJ supplementation in the present study. A-Gonzalez et al. (1) stated that loss of the function of the Liver $X$ receptors led to an increasing in IgG producing cells in the spleen. So, potentially enhanced expression of Liver X receptors with supplementation of PJ can explain lower serum IgG levels of both treatment groups than the control birds in the study. Furthermore, Caldas et al. (6) reported that enhanced Liver X receptors significantly decreased the relative abundance of intestinal 
and renal sodium/phosphate $(\mathrm{NaPi})$ cotransporters. Lacking the NaPi cotransporters causes hypophosphatemia and hypercalciuria (1). It may explain both lower serum phosphorus and serum calcium levels in PJ supplemented birds than the control birds. Also, the constant $\mathrm{Ca}: \mathrm{P}$ ratio despite the decrease in serum $\mathrm{Ca}$ and serum $P$ levels may explain why it had no negative effect on egg production and quality.

As a conclusion, using $5 \%$ of $\mathrm{PJ}$ as a short-term water supplement have some dose-dependent specific effects on the cholesterol metabolism of laying hens rather than performance and immunity of the birds due to the potential effects of abundant phenolic content on reverse cholesterol transport systems in the liver.

\section{Acknowledgements}

The authors thank the staff of Afyon Kocatepe University, Animal Teaching \& Research Center (Afyonkarahisar, Turkey) for their assistance with this study.

\section{Financial Support}

This research received no grant from any funding agency/sector.

\section{Ethical Statement}

The current study was conducted at Afyon Kocatepe University Animal Research Center, Afyonkarahisar, following approval by the Local Ethics Committee on Animal Ethical Use under approval No:49533702/119, dated: 07/09/2016.

\section{Conflict of Interest}

The authors declared that there is no conflict of interest.

\section{References}

1. A-Gonzalez N, Bensinger SJ, Hong C, et al (2009): Apoptotic cells promote their own clearance and immune tolerance through activation of the nuclear receptor LXR. Immunity, 31, 1276-1281.

2. Abbas RJ, Al-Salhie KCK, Al-Hummod SKM (2017): The effect of using different levels of pomegranate (Punica granatum) peel powder on productive and physiological performance of japanese quail (Coturnix coturnix japonica). Livest Res Rural Dev, 29, 1-7.

3. Ahmed ST, Islam MM, Bostami ABMR, et al (2015): Meat composition, fatty acid profile and oxidative stability of meat from broilers supplemented with pomegranate (Punica granatum L.) by-products. Food Chem, 188, 481488.

4. Anonymus (2020): Babcock White product guideline. Available at https://www.babcock-poultry.com/documents/ 562/Babcock_White_CS_cage_ (Accessed December 18, 2020).
5. Bozkurt M, Hippenstiel F, Abdel-Wareth A, et al (2014): Effects of selected herbs and essential oils on performance, egg quality and some metabolic activities in laying hens $-a$ review. Eur Poult Sci, 78, 1-15.

6. Caldas YA, Giral H, Cortázar MA, et al (2011): Liver X receptor-activating ligands modulate renal and intestinal sodium-phosphate transporters. Kidney Int, 80, 535-544.

7. Darvishi H, Khostaghaza MH, Najafi G (2013): Ohmic heating of pomegranate juice: Electrical conductivity and pH change. J Saudi Soc Agric Sci, 12, 101-108.

8. Ghahtan N, Kohanmoo MA, Habibi H (2019): Evaluation of dietary medicinal plants and algae in laying Japanese quails. J World's Poult Res, 9, 82-88.

9. Gil MI, Tomás-Barberán FA, Hess-Pierce B, et al (2000): Antioxidant activity of pomegranate juice and its relationship with phenolic composition and processing. $\mathrm{J}$ Agric Food Chem, 48, 4581-4599.

10. Gozlekci S, Saracoglu O, Onursal E, et al (2011): Total phenolic distribution of juice, peel, and seed extracts of four pomegranate cultivars. Pharmacogn Mag, 7, 161-164.

11. Gultepe EE, Iqbal A, Cetingul IS, et al (2019): Effects of lemon juice on performance, egg quality trait, and some blood parameters of laying hens in the late phase of production. Acta Vet Eurasia, 45, 56-62.

12. Gultepe EE, Iqbal A, Cetingul S, et al (2019): Effect of Myrtus communis L. plant extract as a drinking water supplement on performance, some blood parameters, egg quality and immune response of older laying hens. Kafkas Univ Vet Fak Derg, 25, 1-8.

13. Guvenc A, Akkol EK, Hurkul MM, et al (2012): Wound healing and anti-inflammatory activities of the Michauxia L'Hérit (Campanulaceae) species native to Turkey. Journal of Ethnopharmacology, 139, 401-408.

14. Hou C, Zhang W, Li J, et al (2019): Beneficial effects of pomegranate on lipid metabolism in metabolic disorders. Mol Nutr Food Res, 63, 1800773.

15. Iqbal A, Bayram I, Gültepe EE, et al (2020): Effect of different level of pomegranate molasses on performance, egg quality trait, serological and hematological parameters in older laying hens. Prog Nutr, 22, e2020052.

16. Kostogrys RB, Filipiak-Florkiewicz A, Dereń $\mathrm{K}$, et al (2017): Effect of dietary pomegranate seed oil on laying hen performance and physicochemical properties of eggs. Food Chem, 221, 1096-1103.

17. Littell RC, Stroup WW, Freund RJ (2002): SAS for Linear Models. $4^{\text {th }}$ edition. SAS Institute Inc, Cary, NC, USA.

18. Lv O, Wang L, Li J, et al (2016): Effects of pomegranate peel polyphenols on lipid accumulation and cholesterol metabolic transformation in L-02 human hepatic cells via the PPAR $\gamma$-ABCA1/CYP7A1 pathway. Food Funct, 7, 49764983.

19. Miguel G, Fontes C, Antunes D, et al (2004): Anthocyanin concentration of "Assaria" pomegranate fruits during different cold storage conditions. J Biomed Biotechnol, 2004, 338-342.

20. National Research Council (1994): Nutrient Requirements of Poultry. 9th edition. National Academy Press, Washington, D.C., USA. 
21. Noy Y, Sklan D (1999): Different types of early feeding and performance in chicks and poults. J Appl Poult Res, 8, 1624.

22. Ozkal N, Dinc S (1993): Valuation of the pomegranate (Punica granatum L.) peels from the standpoint of pharmacy. Ankara Univ Eczac Fak Derg, 22, 1-2.

23. Ritzi MM, Abdelrahman W, Mohnl M, et al (2014): Effects of probiotics and application methods on performance and response of broiler chickens to an Eimeria challenge. Poult Sci, 93, 2772-2778.

24. Saki AA, Rabet M, Zamani P, et al (2014): The effects of different levels of pomegranate seed pulp with multi-enzyme on performance, egg quality and serum antioxidant in laying hens. Iran J Appl Anim Sci, 4, 803-808.

25. Saki AA, Shamsollah T, Ashoori A (2019): Egg iron enrichment in response to various levels of pomegranate byproduct in laying hen diet. Iran J Appl Anim Sci, 9, 747754.

26. Şan B, Yildirim AN, Polat M, et al (2015): Chemical compositions of myrtle (Myrtus communis L.) genotypes having bluish-black and yellowish-white fruits. ErwerbsObstbau, 57, 203-210.

27. Sharma MK, Dinh T, Adhikari PA (2020): Production performance, egg quality, and small intestine histomorphology of the laying hens supplemented with phytogenic feed additive. J Appl Poult Res, 29, 362-371.

28. Torshizi MAK, Moghaddam AR, Rahimi S, et al (2010): Assessing the effect of administering probiotics in water or as a feed supplement on broiler performance and immune response. Br Poult Sci, 51, 178-184.

29. Wells RG (1967): Egg shell strength. Br Poult Sci, 8, 193199.

30. Yilmaz B, Usta C (2010). Therapeutic use of pomegranate (Punica granatum). Turkish J Fam Pract, 14, 146-153.

31. Zhao W, Li J, He X, et al (2014): In vitro steatosis hepatic cell model to compare the lipid-lowering effects of pomegranate peel polyphenols with several other plant polyphenols as well as its related cholesterol efflux mechanisms. Toxicol Reports, 1, 945-954. 